\title{
Identity and alternative versions of the past in New Zealand
}

\author{
Geoffrey Clark
}

Archaeology and Natural History, College of Asia and the Pacific, The Australian National University, Australia

\section{Introduction}

During the 1990s, New Zealand/Aotearoa experienced tumultuous debate over indigenous land rights, and the use of Maori culture and language, debate which was associated with the settlement of historical and contemporary grievances between the Crown and Maori. The study of New Zealand's human past during this period became politicised and problematic because different versions of that past could be mobilised to support various agendas and cultural groupings. The redistribution of state-owned resources to Maori through the Waitangi Tribunal process and settlement negotiations with the government gave added intensity to debates about ownership and culturally appropriate use of the past, as did the fact that, with several notable exceptions, most professionally trained historians and archaeologists were of European descent.

The refashioning of the cultural landscape at this time allowed concepts of identity to be destabilised, essentialised and reconstructed. For instance, some people of non-Maori descent, often glossed as 'Pakeha' (but see Goldsmith 2005), who historically belonged to the dominant colonial group, felt threatened by the prospect of a Maori cultural and economic renaissance supported by government redistribution of assets and the assertion that Maori had ancestral rights to New Zealand, as opposed to everyone else. Within Maoridom there were schisms between groups and subgroups involving membership and affiliation, and uncertainty over the rights of urban Maori to access resources through the Waitangi Tribunal. Most of all, if Maori were enshrined as the indigenous people of the land then the non-Maori majority might be considered 'non-indigenous', a term that carries the negative environmental connotations of being foreign, exotic and invasive to the land.

To evade the potentially marginal status implied by a 'non-indigenous' classification many Pakeha appear to have constructed a dual, and I would suggest hierarchical, view of indigeneity in which Maori are held to be the essential indigenous people because they were the first to colonise and inhabit New Zealand, while native-born Pakeha are also held to be indigenous to New Zealand, but less so than Maori because they arrived later. The 1840 Treaty of Waitangi between Maori (tangata whenua, people of the land) and non-Maori (tangata tiriti, people of 
the Treaty) is taken to be the charter that preserves the occupation rights of both groups, but especially colonial-derived Pakeha. When queried, individual Pakeha are in no doubt they are indigenous to New Zealand, but express uncertainty about whether Pakeha as a group can be considered indigenous. This suggests that defining oneself as 'Pakeha' involves, in addition to being 'native born', an element of choice both in rejecting other potential homelands and supporting New Zealand biculturalism by consciously, at some level, asserting Pakeha identity. In short, Maori, it is assumed, cannot be anything other than indigenous, while native-born non-Maori have a choice. The basic division outlined above needs to be tested in public survey, but if it has any validity then it implies a third 'non-indigenous' group composed of non-native migrants/settlers, and native-born people of non-Maori descent who, for whatever reason, reject Pakeha identity, to which the general term 'New Zealander' might apply. The shifting meaning of group identity labels is shown by the common use of the term 'New Zealander' by explorers such as James Cook to describe Maori in the 18th century.

Claims to being 'indigenous', then, stem from the group membership of an individual, either, as I have suggested above, as Maori, Pakeha or New Zealander, or in some other grouping. Whichever is used, to be truly indigenous is usually taken to mean having an ancestral link to the first inhabitants of the land. Alternative prehistories can be used to claim indigenous identity by asserting the arrival of people prior to the arrival of the people held to have been the first arrivals. These claims in New Zealand impinge on the status of Maori as tangata whenua and on orthodox views of the past developed by archaeologists, historians and anthropologists. In this paper, I review the alternative prehistory and activities of the Nation of Waitaha in the turbulent 1990s and the media response of archaeologists and others to allegations that New Zealand had a hidden pre-Maori past. The review illustrates how a manufactured past can be an effective tool in contemporary forums even though the aim in promulgating such views is probably the desire by some non-Maori to realise indigenous status.

\section{The Nation of Waitaha}

Reference is made in this paper to two Waitaha groups, which need to be clearly distinguished from each other. The Maori of New Zealand refer to their earliest actual named ancestors in the South Island as 'Waitaha'. The subsequent arrival of tribes from the North Island, most notably Ngati Mamoe and Ngai Tahu, led to the integration of the Waitaha peoples with these tribes. Thus, 'Waitaha' refers here to those Maori who stress the genuine Waitaha strand of their ancestry. The 'Nation of Waitaha' is the second group. Many individuals in this group cannot legitimately claim Maori or Polynesian descent (O’Regan 1992; Anderson 1998). This group is identified in the text as the 'Nation of Waitaha' or as the 'Nation'.

The genesis of the Nation of Waitaha in the late 1980s is credited by one commentator to two people, Barry Brailsford and Peter Ruka (Tau 1995). Brailsford was a history lecturer at the Christchurch College of Education and had written numerous books including two that dealt with South Island prehistory. Peter Ruka, a secondary school teacher of Maori studies, was involved in gathering data on traditional fishing practices for a Ngai Tahu claim to the Treaty of Waitangi. The Tribunal agreed with Ngai Tahu that Ruka’s fishing evidence was taken from a text book on fishing rather than an unnamed kaumatua (Maori elder) informant as claimed (Tau 1995:6; Ngai Tahu Sea Fisheries Report 1992:3.4.9). In 1988, Brailsford and Ruka were engaged to write a book on the interaction between South Island Maori (Rapuwai, Waitaha, Ngati Mamoe and Ngai Tahu) and the environment, based largely on archaeological data. The decision for book funding was made after an approach to the Minister of Internal Affairs. However, by 1989 Maori support for the project was withdrawn by Ngai Tahu, the major 
South Island tribe. Brailsford claimed the work was based on the teachings of Te Maiharoa and Puao Rakiraki, but tribal historians found his texts had no similarity to tribal manuscripts written by their descendants and students such as Wikitoria Paipeta, Wi Pokuku, Hoani Kaahu and Herewini Ira (Prendergast-Tarena 2008). Ruka's genealogical connection to Ngai Tahu and knowledge of tribal matters was also challenged by tribal elders (O'Regan 1992; Tau 1995).

Brailsford received an MBE for his contribution to education and Maori scholarship in 1990, but by then the book's direction had taken a radical turn. In media reports from 1990 to 1991 the Nation of Waitaha members identified themselves as distinct from Ngai Tahu, the tribe which had withdrawn project support, and were asserting that their culture and history had been secretly preserved by unnamed Waitaha Elders (Dominion Sunday Times, 9 December 1990; The Press, 5 November 1991). The Nation of Waitaha claimed to be the first people in New Zealand and culturally distinct from later Maori arrivals, especially Ngai Tahu, which was portrayed as a warrior culture more concerned with securing economic assets from the Crown than with matters spiritual or environmental (O’Regan 1992).

\section{Song of Waitaba}

The Nation of Waitaha published its prehistory, entitled Song of Waitaha: The histories of a nation, in 1994. A new edition was published in 2003 and a companion volume Whispers of Waitaha (2006) is advertised online as: 'Pre Maori Folklore, Traditions and Oral Histories of the Waitaha people'.

The version of New Zealand's past contained in the 311-page Song of Waitaha can be characterised as alternative in the sense that while it has a semblance to conventional history for example, some place names and the names of some gods and ancestors conform to published sources - it adds completely new elements, and provides a quite different chronological framework for events which are also said to have unfolded in locations that are foreign to most oral traditions (e.g. Shortland 1851; Anderson 1998; Prendergast-Tarena 2008).

According to Song of Waitaha, the world in the deep past was regularly traversed by different races of people using canoes which moved on sea-highways called Long Tides. An important focus for these journeys was the island of Waitangi Ki Roto, which can, using maps and textural details, be equated with Easter Island/Rapa Nui (Brailsford 1994:158-159; Howe 2003:146). An early and important figure from Waitangi Ki Roto was the well-known Polynesian demigod Maui who visited the South Island and dragged the North Island from the sea. He also discovered the birth place of the gods Te Kohanga in the South Island and, on departing, left four tribes (Maoriori, Moriori, Pakau and Maruiwi).

Further visits to and from Waitangi Ki Roto and Aotea Roa (South Island)-Whai Repo (North Island) followed, with Tamatea Mai Tawhiti visiting 70 generations ago (ca. 1750-2100 years ago) and, Ngahue and then Ra Kai Hau Tu 67 generations ago. Some of the ancestral personalities, like Ra Kai Hau Tu, are well known in New Zealand and can be found in the traditional genealogies of Northland, the South Island and Polynesia, but new elements are introduced beneath the veneer of tradition. For example, Ra Kai Hau Tu in Song of Waitaha does not appear to be Polynesian and is described as having pale skin and blue eyes (Brailsford 1994:99).

Greenstone (nephrite) was supposedly carried to Waitangi Ki Roto (Brailsford 1994:157), while kumara (sweet potato) was moved to New Zealand and planted at Te Kohanga - an area outside the climatic tolerance of this crop. New people arrived and were subsumed under the names of Waitaha and Rapuwai. These included the skilled canoe navigators called Urukehu, who were pale-skinned, blue-eyed and short-statured, the gardening Maoriori, distinguished 
by their tallness and dark colouring, and the Tu Takapo/Kiritea, or Stone People, with dark hair, light-brown coloured skin and a double fold over their eyelids (Brailsford 1994:57, 135; Brailsford in Paterson 1994).

The utopian lifestyle of the Nation, complete with schools of learning, a gardening culture and distinctive set of ceremonial activities, came to an end with the arrival of warriors from the Pacific. This happened gradually, with the North Island falling first and then the arrival of Tu Ma Tauenga signalling the destruction of the peaceful Waitaha Nation and the concealing of its history (Brailsford 1994:294).

Of the many prehistoric events listed in Song of Waitaha there are few which can be examined using archaeological data and then only through negative evidence. There are claims, for example, that the Nation had the knowledge to construct clay items (Brailsford 1994:186) and had introduced different types of potato and sweet potato into New Zealand (Brailsford $1994: 11,140,143)$, in addition to transporting greenstone to Easter Island and other places (Brailsford 1994:157). Evidence for these activities has not been found, nor is there any sign that pre-Maori settlements existed at the locations of the principal villages of the Nation.

The issue of chronology is perhaps the weakest part of the Nation's prehistory, as an extensive suite of radiocarbon determinations from cultural and environmental contexts strongly supports the conclusion that Maori arrived from East Polynesia about 700 years ago (e.g. Anderson 1991; Wilmshurst et al. 2010). There are references to large stone monuments at Te Kohanga and other places such as the sub-Antarctic Auckland Islands (Brailsford 1994:185-188), but only Nation of Waitaha adepts can distinguish these from natural formations. An entwined spiritual-conservation ethic was said to allow the Nation of Waitaha to live in harmony with the environment (Brailsford 1994:182, 235, 260, 289), presumably to such a degree that a conventional prehistoric landscape did not form. Deforestation and the extinction of bird species is attributed to cataclysmic natural phenomena (Brailsford 1994:52, 287-289), in contrast to results from archaeological and palaeoenvironmental research that suggest many large-scale environmental changes were wrought by prehistoric people (e.g. Anderson 1989; Worthy and Holdaway 2002; Wilmshurst et al. 2008).

All of this would be of little importance if Song of Waitaha was, like conventional prehistories, advanced as a competing view of the past which the community could either accept or reject. But, unlike most conventional prehistory, the prehistory of the Nation of Waitaha had the potential to threaten Maori rights: '... various ideologies arising from Brailsford's work - while appearing harmless on the surface - may in fact, by reconstructing Pakeha and other nonMaori as equally Indigenous to Aotearoa [New Zealand] have more far-reaching consequences threatening ultimately to undermine the status of Maori as Tangata Whenua' (Liddell 1997:32). In addition, the Nation of Waitaha was active in promoting its view of the past and achieved considerable success in obtaining resources and a public identity.

\section{Publication and media coverage}

Despite the damaging withdrawal of Ngai Tahu support, considerable funds were given to support publication of Song of Waitaha from the Ministry of Education, the New Zealand 1990 Commission, and various corporations, including Toyota New Zealand, the National Bank and Air New Zealand, among groups providing financial and logistical support (Brailsford 1994; King 1995). Two sources estimate that at least $\$ 500,000$ was spent on the project (O'Regan 1992; A. Anderson pers. com. 1998). Song of Waitaha was published in 1994, but it is unclear how many copies were initially printed. The pre-publication cost of the book was $\$ 60$, with a recommended retail value of $\$ 89.95$. A special edition run of 525 copies, priced at $\$ 750$ each, was also advertised. 
Apart from the financial benefits associated with publication, the Nation of Waitaha, some members of which had strong links to the education sector, planned to distribute a copy of the book to every New Zealand high school (Paterson 1994:35). Out of 12 high schools from the North and South Island contacted by the author in 1998 six had a copy of the book. The standard text on New Zealand's past is The Prehistory of New Zealand, written by Janet Davidson (1984), yet it seems likely, considering the amount of funding involved, that Song of Waitaha has an equally wide distribution within the education system. Thus, there is every reason to believe that in some schools Brailsford's book will have been used as a genuine teaching and research resource by teachers and students. Exactly how Song of Waitaha was used in the education sector is unclear. For example, six copies of the book held by the National Library of New Zealand Schools Collection have been heavily used in Auckland and Christchurch. However, one school librarian noted that students are intimidated by the book's size and tend not to use it for research purposes (T. Agnew pers. com. 1998).

Media reports about prehistory commonly focus on new discoveries, especially results which suggest a much greater age for human occupation than has previously been considered. The Nation was able to exploit the media's predisposition for these themes and in 1996 received sustained media coverage. In late April an article in the popular weekly magazine, The Listener (circulation ca. 100,000; Country Press 1997/1998), reported Brailsford's belief that a stone outcrop in the Kaimanawa Forest Park in the Central North Island was evidence of a pre-Maori megalith culture. The article, titled 'Megalith Mystery: Are giant stones in the Kaimanawa Forest Park evidence of an Ancient New Zealand culture?' gave the Nation an unprecedented amount of coverage in the electronic and print media (Table 1; Ritchie 1996). No other story dealing with the prehistory of New Zealand in the 10 years (1996-2006) for which records were examined by the author generated as much media coverage. Headlines on the Kaimanawa wall suggest two stages of reporting. The first is the 'mystery' versus the 'no-mystery' viewpoints, where archaeologists and geologists debated with the Nation of Waitaha (Table 1). Critical in keeping public interest alive was a media quote from a scientist that the wall was highly likely' to be of human construction. Towards the end of the media's interest, which lasted about two weeks, and following the identification of the wall as a natural formation, a strong Maori reaction, culminating in a ban on the site, halted research. As the story breaker, Brailsford's views were prominent in much of the media coverage, while those from prehistorians received limited treatment (Table 1). Archaeologists were hampered by having to comment on a geological formation with little time for detailed study.

Nonetheless, the limited public response from professional archaeologists to the Waitaha Nation's assertion that the Kaimanawa wall was evidence for pre-Maori population was somewhat perplexing, given that the story, regardless of how one views Brailsford's opinions, was about the prehistory of New Zealand and through the media had reached a large public audience. For example, the New Zealand Archaeological Association decided not to issue a press release as it was felt that the Kaimanawa wall was not an archaeological issue (M. White pers. com. 1996).

The Nation of Waitaha defused archaeological criticism by focusing on geological features, but it is also worth noting that relations between Maori and archaeologists were substantially reshaped by the activities of the Waitangi Tribunal during the 1990s, particularly the use of archaeological data to assist in identifying the antiquity and extent of tribal activities to formally establish manawhenua (authority over land). Archaeologists and historians critical of indigenous history, even that of alternative groups like the Nation of Waitaha, could be seen as colonial, repressive and acting against indigenous interests and negotiations, often fractious, between Maori and the Crown. The limited public response of New Zealand archaeologists to the Nation 
Table 1. Media coverage of the claim that the Kaimanawa wall was of pre-Maori origin.

\begin{tabular}{|c|c|c|}
\hline Newspaper & Date & Headline \\
\hline 1. New Zealand Herald & 1 May & Great Wall of Kaimanawas theory rubbished by experts \\
\hline 2. New Zealand Herald & 3 May & Mystery surrounds origins of the Kaimanawa wall \\
\hline 3. The Listener & 29 April - 4 May & Megalith mystery \\
\hline 4. The Dominion & 6 May & Experts none the wiser about wall \\
\hline 5. Daily News & 7 May & American joins debate on mystery stone wall \\
\hline 6. New Zealand Herald & 8 May & Excavations to uncover wall secrets \\
\hline 7. Evening Post & 8 May & Theory of ancient wall rejected by historians \\
\hline 8. Evening Standard & 9 May & It's a hoax, says historian \\
\hline 9. Daily Telegraph & 9 May & Wall game may make Maoris the losers \\
\hline 10. Daily Telegraph & 9 May & Wall a lava flow, says historian \\
\hline 11. Taupo Times & 10 May & Rock wall not part of mill \\
\hline 12. New Zealand Herald & 10 May & Theories on ancient settlers rise from forest's rock pile \\
\hline 13. New Zealand Herald & 10 May & Excavations to uncover wall secrets \\
\hline 14. Taupo Times & 11 May & Leave wall investigation to experts, DOC urges \\
\hline 15. Taupo Times & 11 May & Site off limits to public, says Maori spokesperson \\
\hline 16. Daily Post & 11 May & Wall raises racism claims \\
\hline 17. Otago Daily Times & 13 May & Maoris debate fate of controversial wall \\
\hline 18 The Dominion & 14 May & Kaimanawa wall off limits: Taupo Maori \\
\hline 19. New Zealand Herald & 14 May & Kaimanawa wall a natural volcanic rock formation \\
\hline 20. Otago Daily Times & 15 May & Ban placed on wall \\
\hline 21. The Press & 15 May & Tribe puts ban on tampering with wall \\
\hline 22. Evening Post & 25 May & In search of lost civilisations \\
\hline Commentator & Number of stories $(n=22)$ & Description by newspaper and story reference \\
\hline Barry Brailsford & 18 & $\begin{array}{l}\text { rebel historian (1), specialist in South Island Maori history (1), Christchurch geologist (2), } \\
\text { maverick of archaeology in New Zealand (3), [former] archaeologist and history lecturer at } \\
\text { Christchurch Teachers College (3), South Island geologist (12), Hamilton archaeologist (20) }\end{array}$ \\
\hline David Hatcher Childress & 15 & $\begin{array}{l}\text { American archaeologist (3), author of popular books (4), United States ancient history } \\
\text { researcher (11), visiting American archaeological researcher (12), American historian (16) }\end{array}$ \\
\hline Neville Ritchie & 6 & $\begin{array}{l}\text { Doctor and senior Department of Conservation archaeologist (12), nationally acclaimed } \\
\text { expert on walls (19), archaeologist (4) }\end{array}$ \\
\hline Perry Fletcher & 4 & $\begin{array}{l}\text { from the New Zealand Archaeological Association (11), Taupo historian (8), local historian } \\
\text { (4), file keeper for the Bay of Plenty branch of the NZ Archaeology Association (8) }\end{array}$ \\
\hline Peter Adds & 4 & Victoria University Maori Studies senior lecturer (17) \\
\hline Kerry Howe & 2 & Professor of history from Massey University (8) \\
\hline Peter Wood & 2 & $\begin{array}{l}\text { Doctor and geothermal geologist (2), a Geological and Nuclear Sciences Institute specialist } \\
\text { in ignimbrite (19) }\end{array}$ \\
\hline Janet Davidson & 1 & author of The prehistory of New Zealand (22) \\
\hline Harry Keys & 1 & Doctor and scientist for the Taupo-Turangi conservancy (2) \\
\hline Geoff Irwin & 1 & Professor and specialist in Pacific archaeology (1) \\
\hline Trevor Hosking & 1 & former New Zealand Historic Places archaeologist (14) \\
\hline Rex Gilroy & 1 & Director of the Australia-Pacific Archaeological Research Centre (22) \\
\hline
\end{tabular}


of Waitaha's alternative prehistory can be compared with Australia where $25 \%$ of all print media reports on the controversial (and later rejected) claim made in 1996 that the Jinmium site in Australia was 176,000 years old were written by archaeologists.

Media and public interest in the Kaimanawa wall was further developed by Brailsford and the American alternative prehistorian David Hatcher Childress, who gave a joint seminar (11 May 1996) at the Auckland College of Education on the ancient megalithic cultures of the Pacific. The seminar was mentioned in the initial Listener article and later advertised in daily newspapers, and, at a cost of $\$ 35$ per person, reportedly was well attended. The Nation of Waitaha in the 1990s continued to receive publicity using alternative prehistory to attract the media and the public to its view of the past. Earthworks found in Northland were identified in the New Zealand and Australian media as the remains of an ancient Waitaha village. The reports carried the headlines 'Pre-Maori tribe theory gains support' and 'Ancient earthworks casts doubt over Maoris' claim to be first settlers' (NZ Herald, 2 June 1998; Sydney Morning Herald, 13 June 1998).

\section{Indigenous identity}

Media and publishing activities helped the Nation of Waitaha to be seen as an authentic indigenous group. Ngai Tahu, which now has tribal authority over more than $80 \%$ of the South Island, had, since 1986, negotiated with the Crown for the return of land and sea assets taken from it after the signing of the Treaty of Waitangi in 1840. The success of Ngai Tahu in arguing its case led the Crown to offer a $\$ 170$ million package through the Ngai Tahu Claims Settlement Bill which was passed by Parliament on 29 September 1998. Before the settlement, factions from within Ngai Tahu, most notably members who have actual Waitaha ancestry (as, in fact, do nearly all Ngai Tahu), and who had discovered a potential strength in alliance with the Nation of Waitaha, argued that their rights would be extinguished under the Bill (The Press, 22 May 1998). O'Regan (1992) has suggested that factions like the Nation of Waitaha form and agitate in order to capture resources and funds when the opportunity to do so arises.

A desire for an authentic indigenous identity also helps to explain the content of Song of Waitaha and the activities of the Nation of Waitaha, which had a potentially large and cosmopolitan membership. Brailsford is quoted in a New Age publication as saying: 'we are all tangata whenua ... the white ones with their freckles and blue eyes and blonde hair, the dark ones who go to the gardens, the snow people from the Asian lands. We are all part of this land' (in Paterson 1994:34). In a later book, Brailsford (1995) who is of European ancestry, claimed direct descent from the founding Waitaha ancestor Rakaihautu.

Ko Barry Brailsford
Ko Tuhua te maunga
Ko Mawhera te awa
Ko Te Aka Aka o Poutini te marae
Ko Rakaihautu te tupuna
Ko Waitaha te iwi
(Brailsford 1995:9)

One Waitaha group with links to Brailsford specified that members of Waitaha were those who could conventionally trace their ancestry (whakapapa) from and through Rakaihautu, in addition to honorary members who could be Maori and Pakeha who were not of Waitaha (Waitaha Taiwhenua O Waitaki Trust Board 1996). What is perhaps unique to Waitaha was this fusion of disgruntled but genuine groups within Maoridom with non-Maori in the Nation of 
Waitaha. One example is that some Waitaha claimed an antiquity of 67 generations as in the Song of Waitaha when arguing for their status as a distinct and older indigenous group than Ngai Tahu (Otago Daily Times, 17 June 1998; The Press, 10 July 1998).

It is not possible now to estimate how many people claimed to be part of the Waitaha Nation or the Nation's ethnic composition, because of the confusion between the two Waitaha groups. One Waitaha leader said that about 270 people from the South Island and 1000 in the North Island had registered as Waitaha (Otago Daily Times, 17 June 1998), while a Nation of Waitaha elder noted a similar total figure, but had the majority resident in the South Island (NZ Herald, 2 June 1998).

\section{Conclusion}

The late Michael King $(1994,1995,2003)$ saw the Song of Waitaha as yet another example of colonialism affecting indigenous cultures through European appropriation and transmutation of the Maori past into synthetic forms. One of the ironies about the views contained in Song of Waitaha for archaeologists and historians is their similarity to ideas found in earlier and longdiscarded scholarship. Elsdon Best and Percy Smith, both eminent workers in the emerging field of Maori studies, advanced the idea of a pre-Maori population called the Maruiwi/Moriori in a series of papers published in the Journal of the Polynesian Society (Smith 1913-15; Best 1913-14, 1916, 1928). The peaceful Maruiwi/Moriori were said to have been killed, assimilated or driven to the Chatham Islands by Maori. There are similarities between Song of Waitaha and these earlier studies, both in substance and style, which suggests a degree of familiarity with long-abandoned works like the Lore of the Whare-wananga, Tuhoe-Children of the Mist, and Adkin's $(1950,1960)$ thesis of a pan-New Zealand Waitaha tribe 2100 years old. Hyperdiffusionist explanations of cultural dispersal in the late 19th and early 20th centuries provide a permanent reservoir (e.g. Haast 1872; Tregear 1904; Brown 1907, 1924) of outdated and discredited ideas that alternative prehistorians will refer to and use (e.g. Childress 1995). One publisher of alternative prehistory in New Zealand (Dé Danaan Publishers) wants to: '... restore full integrity to the reliable works of Historians of the 19th and 20th centuries and those first hand accounts of New Zealand's colonial history, which have been supplanted by modern works written by social historians with P.C. agendas'. It is noteworthy that hyper-diffusionist and preMaori explanations of New Zealand's past supported colonial occupation by viewing history as a series of population movements by progressively more advanced ethnic groups which, along with their plants and animals, naturally supplanted those of the indigenous ecosystem. As others have pointed out, it is astonishing how the idea of a pre-Maori population periodically returns in a new guise (O'Regan 1992; Anderson 1998:21), in spite of the idea and its sources suffering frequent criticism in scholarly circles (Williams 1937; Golson 1960; Simmons 1976).

One explanation for the popularity of alternative prehistories in New Zealand during the 1990s might lie in the changing cultural spaces created by the activities of the Waitangi Tribunal between different sectors of New Zealand society, particularly the new relationships forged between the Crown and Maoridom. The alienation of some non-Maori and Maori from the redistribution-reconciliation process fostered a range of prehistories that proposed the colonisation of New Zealand by, among others, Celts, Phoenicians, Vikings, Chinese and South Americans (e.g. Wiseman 1998, 2001; Bolton 1999; Doutré 1999; Tasker 1999). Several published and online alternative prehistories explicitly state that the 'fact' of pre-Maori occupation extinguishes Maori rights under the Treaty of Waitangi. In summary, the argument runs that if Maori were preceded by another people, and they killed the Maruiwi/Moriori and took their lands by force, then European settlement and the subsequent alienation of Maori 
land is simply another example of social-Darwinism - with the weak making way for the strong. Further, the redistribution of state-owned assets under the Treaty of Waitangi is not warranted because the original inhabitants have been extirpated.

The Song of Waitaha is relatively benign in comparison with several of the more malignant alternative prehistories, although the Nation of Waitaha in the 1990s had the potential to unsettle and complicate the Ngai Tahu settlement, and contributed a unorthodox view of New Zealand's past that achieved a much wider distribution than others in the genre through its New-Age message and strategic use of publishing and the media. As has been noted, the descendents of settler societies occupy an uncertain cultural space between the 'mother' and the 'other' (Lawson 1995:25), and in post-colonial settings, group identity is constantly refashioned from conventional and unorthodox sources. Archaeologists and others involved in historical research need to be aware of the content, influences and activities of individuals and groups promoting alternative versions of the past, and mindful of the desire for indigeneity that is frequently embedded in them (Goldsmith 2009).

\section{Acknowledgements}

I would like to thank Atholl Anderson for access to his Nation of Waitaha file and his pertinent comments on previous drafts of this paper. Others who provided valuable feedback and comments during the paper's long development include Sir Tipene O'Regan, Michael Goldsmith, Matthew Campbell, Janet Davidson, Jack Golson, Kirsten Lawson, Foss Leach, and Michael King. Ailisa Cornelius (School Library Network), Kingsley Field (NZ Herald), Don Lawson (Kaikorai Valley High School), Rachel Lawson (Victoria University Press) and Kathy Prickett (Auckland Institute and Museum), and Neville Ritchie (Department of Conservation) kindly supplied information and answered queries. The opinions and content expressed in this paper are, however, the responsibility of the author alone. 


\section{References}

Adkin, G.L. 1950. Supplementary data relating to the ancient Waitaha in the Horowhenua - Te Whanga-nui-a-tara area, North Island, New Zealand. Journal of the Polynesian Society 59:1-34.

Adkin, G.L. 1960. An adequate culture nomenclature for the New Zealand area. Journal of the Polynesian Society 69:228-238.

Agnew, T. Hillmorton High School, Christchurch. Personal communication, 17 September 1998.

Anderson, A. 1989. Prodigious birds. Moas and moa-hunting in prehistoric New Zealand. Cambridge University Press, England.

Anderson, A. 1991. The chronology of colonization in New Zealand. Antiquity 65:267-295.

Anderson, A. 1998. The welcome of strangers. University of Otago Press, Dunedin.

Anderson, A. Research School of Pacific and Asian Studies, Australian National University. Personal communication, October 1998.

Best, E. 1913. Tuhoe - The children of the mist. Journal of the Polynesian Society 22:149-167.

Best, E. 1914. Tuhoe - The children of the mist. Journal of the Polynesian Society 23:38-54, 159-172.

Best, E. 1916. Maori and Muruiwi. Transactions of the New Zealand Institute 48:435-447.

Best, E. 1928. Maori and Muruiwi. Journal of the Polynesian Society 37:175-225.

Bolton, K.R. 1999. Lords of the soil: The story of the Turehu, the White Tangata Whenua. Spectrum Press, Waikanae.

Brown, J.M. 1907. Maori and Polynesian: Their origin, history and culture. Hutchinson, London.

Brown, J.M. 1924. The riddle of the Pacific. Fisher Unwin, London.

Brailsford, B. 1994. Song of Waitaha: The histories of a nation. Ngatapuwae Trust, Christchurch.

Brailsford, B. 1995. Song of the stone. Stoneprint Press, Hamilton.

Childress, D.M. 1995. Lost cities of ancient Lemuria and the Pacific. Adventure Unlimited Press, Illinois.

Country Press. 1997/1998. Press, radio and T.V. guide. Media Monitors NSW, Sydney, Australia.

Davidson, J.M. 1984. The prehistory of New Zealand. Longman Paul, Auckland, New Zealand.

Doutré, M. 1999. Ancient Celtic New Zealand. Dé Danaan Publishers, Auckland.

Goldsmith, M. 2005. Translated identities: 'Pakeha' as subjects of the Treaty of Waitangi. SITES: New Series 2(2):64-82.

Goldsmith, M. 2009. Struggling to be indigenous. Paper given at the Association for Social Anthropology in Oceania session at Santa Cruz, California.

Golson, J. 1960. Archaeology, tradition, and myth in New Zealand prehistory. Journal of the Polynesian Society 69(4):380-402.

Haast, J. 1872. Moas and Moahunters. Address to the Philosophical Institute of Canterbury. Transactions of the New Zealand Institute 4:66-90.

Howe, K.R. 2003. The quest for origins. Penguin Books, New Zealand.

King, M. 1994. Repairing the damage. Metro 155 (May):141-142.

King, M. 1995. The secret history. Metro 164 (February):120.

King, M. 2003. The Penguin history of New Zealand. Penguin Books, New Zealand.

Lawson, A. 1995. Postcolonial theory and the 'Settler' subject. Essays on Canadian Writing 56(Fall):20-36.

Liddell, T. 1997. The travesty of Waitaha: The New Age piracy of early Maori history. In: Pihama, L. and Waerea-i-te-rangi Smith, C. (eds), Cultural and intellectual property rights. Economics, politics \& colonisation, Volume 2, pp. 32-43. International Research Institute for Maori and Indigenous Education, University of Auckland, Tamaki Makaurau.

Ngai Tahu Sea Fisheries Report. 1992. Waitangi Tribunal, Department of Justice, Wellington.

O'Regan, T. 1992. Old myths and new politics. Some contemporary uses of traditional history. The New Zealand Journal of History 26:5-27.

Paterson, K. 1994. Waka of dreams. New Spirit (August) 21:34-35.

Prendergast-Tarena, E.R. 2008. He Atua, He Tipua, He Takata Ranei: The dynamics of change in South Island oral traditions. Unpublished MA thesis, University of Canterbury.

Ritchie, N.A. 1996. A new age myth: The Kaimanawa 'wall'. Archaeology in New Zealand 39(3):175-183. 
Shortland, E. 1851 [1974]. The Southern Districts of New Zealand. Capper Press, Christchurch. Simmons, D.R. 1976. The great New Zealand myth. A.H. Reed and A.W. Reed, Wellington, Auckland, Christchurch.

Smith, S.P. 1913. The Lore of the Whare-wananga. Journal of the Polynesian Society 22:3-24, 45-61, 107-133, 169-218.

Smith, S.P. 1914. The Lore of the Whare-wananga. Journal of the Polynesian Society 23:1-18, 61-83, 127-149, 181-218.

Smith, S.P. 1915. The Lore of the Whare-wananga. Journal of the Polynesian Society 24:1-23.

Tasker, J. 1999. Chain of evidence - Who were the first humans to visit New Zealand? Kanuka Press, New Zealand.

Tau, R. Te M. 1995. Song of Waitaha - a descendant's point of view. Te Karaka (Spring) 6-7:20.

Tregear, E. 1904. The Maori Race. A.D. Willis, Wanganui, New Zealand.

Waitaha Taiwhenua O Waitaki Trust Board (HN/826450) Certificate of Incorporation, 1996. Ministry of Commerce Te Manatu Tauhokohoko.

White, M. New Zealand Archaeological Association. Personal communication, October 1996.

Wilmshurst, J.M., Anderson, A.J., Higham, T.F.G. and Worthy, T.H. 2008. Dating the late prehistoric dispersal of Polynesians to New Zealand using the commensal Pacific rat. Proceedings of the National Academy of Sciences, USA 105(22):7676-7680.

Wilmshurst, J.M., Hunt, T.L., Lipo, C.P. and Anderson, A.J. 2010. High-precision radiocarbon dating shows recent and rapid initial colonization of East Polynesia. Proceedings of the National Academy of Sciences, USA doi/10.1073/pnas.1015876108.

Williams, H.W. 1937. The Maruiwi myth. Journal of the Polynesian Society 46:105-122.

Wiseman, R.M. 1998. Pre-Tasman explorers. Discovery Press, Auckland.

Wiseman, R.M. 2001. New Zealand's hidden past. Discovery Press, Auckland.

Worthy, T.H. and Holdaway, R.N. 2002. The lost world of the Moa. Indiana University Press, Bloomington.

\section{Newspaper reports}

The Dominion Sunday Times, 9 December 1990. New book will reveal secret history of the Maori.

The New Zealand Herald, 2 June 1998. Pre Maori tribe theory gains support.

The Otago Daily Times, 8 May 1997. Historian touring South Island promoting new editions of books.

The Otago Daily Times, 17 June 1998. Subsumption key to Waitaha debate.

The Press, 5 November 1991. Waitaha make their stand.

The Press, 22 May 1998. Separate SI tribes reject $\$ 170 \mathrm{~m}$ treaty settlement.

The Press, 19 June 1998. Waitaha wins right to challenge settlement.

The Press, 10 July 1998 . Will the real Waitaha stand up?

The Press, 10 August 1998. Letter to the Editor.

The Southland Times, 9 May 1997. Evidence of human life in Southland from 1178.

The Sydney Morning Herald, 13 June 1998. Ancient earthworks casts doubt over Maoris' claim to be first settlers. 